OPEN ACCESS

Approved by:

Frontiers Editorial Office

Frontiers Media SA, Switzerland

*Correspondence:

Paul William Young

p.young@ucc.ie

Specialty section:

This article was submitted to

STEM Education,

a section of the journal

Frontiers in Education

Received: 15 August 2020

Accepted: 26 August 2020

Published: 25 September 2020

Citation:

Young PW (2020) Corrigendum

Student-Produced Video of

Role-Plays on Topics in Cell Biology

and Biochemistry: A Novel

Undergraduate Group Work Exercise.

Front. Educ. 5:595165.

doi: 10.3389/feduc.2020.595165

\section{Corrigendum: Student-Produced Video of Role-Plays on Topics in Cell Biology and Biochemistry: A Novel Undergraduate Group Work Exercise}

\author{
Paul William Young* \\ School of Biochemistry and Cell Biology, University College Cork, Cork, Ireland
}

Keywords: video, role-playing, cell biology, group work, collaborative learning, graduate attributes

\section{A Corrigendum on}

Student-Produced Video of Role-Plays on Topics in Cell Biology and Biochemistry: A Novel Undergraduate Group Work Exercise

by Young, P. W. (2020). Front. Educ. 5:115. doi: 10.3389/feduc.2020.00115

In the original article, we neglected to include acknowledgment of a National University of Ireland, Publication Grant to Paul Young, which was received after the article had gone to press.

\section{ACKNOWLEDGMENTS}

I am extremely grateful to the 2018/2019 BC3003 students, as well as those from previous years, who have contributed their creativity and hard work in such a positive way to the development of this role-play format. I also thank Dr. Kellie Dean, as well as the attendees of a Technology Enhanced Learning session at University College Cork for critical insights and ideas that have contributed to this paper. I acknowledge the support of a publication grant from the National University of Ireland toward the publication costs of this article.

The authors apologize for this error and state that this does not change the scientific conclusions of the article in any way. The original article has been updated.

Copyright () 2020 Young. This is an open-access article distributed under the terms of the Creative Commons Attribution License (CC BY). The use, distribution or reproduction in other forums is permitted, provided the original author(s) and the copyright owner(s) are credited and that the original publication in this journal is cited, in accordance with accepted academic practice. No use, distribution or reproduction is permitted which does not comply with these terms. 